\title{
HUBUNGAN KARAKTERISTIK DAN TINGKAT PENGETAHUAN DENGAN PERILAKU PENCEGAHAN COVID-19PADA MASYARAKAT DESA PAYA BUJOK BLANG PASE KOTA LANGSA
}

\author{
Khairunnisa Z, Rizka Sofia, Sulfia Magfirah \\ Program Studi Kedokteran, Fakultas Kedokteran, Universitas Malikussaleh \\ J1. H. Meunasah Uteunkot Cunda Muara Dua, Lhokseumawe, Indonesia, 24352, Telp/Fax:- \\ khairunnisa@unimal.ac.id
}

\begin{abstract}
Covid-19 is a global outbreak that is not ended yet and a significant amount of positive cases are keep increasing. Positive cases and the death rates are increasing in Indonesia, therefore it is necessary to break the chain to prevent the spread of Covid-19. The purpose of this research is to find out the relation between characteristics and knowledge levels with prevention behavior of Covid-19 in society of Paya Bujok Blang Pase Langsa City. The research method that has been used was an analytical study with cross sectional design and the statistical analysis was the chi square test. The sampling technique in this research used a simple random sampling with a total of 260 people according to inclusion and exclusion criteria. The results of the univariate analysis found that the highest level of knowledge was good (73.5\%), and the highest level of behavior was good (67.7\%). The results of the bivariate analysis found that there was no relationship between gender and Covid-19 prevention behavior ( $p$ value 0.427), there was no relationship between work and Covid-19 prevention behavior ( $p$ value 0.230), and there was a relationship between age, education, and knowledge with Covid-19 prevention behavior ( $\mathrm{p}$ value 0.000). The conclusion of this research is there is no relationship between gender and work with Covid-19 prevention behavior and there is a relationship between age, education, and level of knowledge with Covid-19 prevention behavior.
\end{abstract}

Keywords: Covid-19, characteristics, level of knowledge, behavior

Abstrak

Covid-19 merupakan wabah global yang hingga kini belum berakhir dan terus terjadi penambahan kasus positif yang signifikan. Kasus positif dan angka kematian di Indonesia semakin meningkat, oleh karena itu diperlukan upaya pemutusan mata rantai penyebaran Covid-19. Tujuan penelitian ini adalah untuk mengetahui hubungan karakteristik dan tingkat pengetahuan dengan perilaku pencegahan Covid-19 pada masyarakat Desa Paya Bujok Blang Pase Kota Langsa. Metode penelitian yang digunakan adalah studi analitik dengan desain cross sectional dan analisis statistik menggunakan uji chi square. Pengambilan sampel pada penelitian ini menggunakan teknik simple random sampling dengan jumlah 260 masyarakat yang telah memenuhi kriteria inklusi dan ekslusi. Hasil analisis univariat didapatkan bahwa tingkat pengetahuan terbanyak yaitu kategori baik (73,5\%), dan perilaku terbanyak yaitu kategori baik (67,7\%). Hasil analisis bivariat didapatkan bahwa tidak terdapat hubungan antara jenis kelamin dengan perilaku pencegahan Covid-19 ( $p$ value 0,427), tidak terdapat hubungan antara pekerjaan dengan perilaku pencegahan Covid-19 ( $p$ value 0,230), dan terdapat hubungan antara usia, pendidikan, dan pengetahuan dengan perilaku pencegahan Covid-19 ( $p$ value 0,000). Kesimpulan penelitian ini adalah tidak terdapat hubungan antara karakteristik jenis kelamin dan pekerjaan dengan perilaku pencegahan Covid-19 dan terdapat hubungan antara usia, pendidikan, dan tingkat pengetahuan dengan perilaku pencegahan Covid19.

Kata kunci: Covid-19, karakteristik, tingkat pengetahuan, perilaku

\section{PENDAHULUAN}

Covid-19 merupakan wabah global yang hingga kini belum berakhir dan terus terjadi penambahan kasus positif yang signifikan. Secara global, telah dilaporkan sebanyak 25.327 .098 kasus konfirmasi Covid- 19 di 215 negara dengan 848.255 jiwa yang meninggal sampai dengan tanggal 1 September 2020 (Kemenkes RI, 2020). Penyebaran kasus positif terjadi secara cepat di berbagai negara dan dinyatakan sebagai pandemi pada 11 Maret 2020 oleh World Health Organization (WHO) (World 
Health Organization, 2020).

Covid-19 berawal dari daerah Wuhan, provinsi Hubei, China sejak Desember 2019 yang disebabkan oleh virus corona. Awal kemunculannya diprediksi merupakan penyakit pneumonia gawat yang tidak diketahui dan belum pernah menyerang manusia sebelumnya. Virus ini tumbuh dan berkembang dengan cepat hingga menyebabkan peradangan lebih parah serta gagal organ dan juga kematian (D. Sari \& 'Atiqoh, 2020). Hingga kini virus corona terus menyebar di seluruh dunia dan telah menginfeksi 216 negara termasuk Indonesia (Kemenkes RI, 2020b).

Di Indonesia, kasus Covid-19 pertama kali dikonfirmasi pada tanggal 2 Maret 2020 sejumlah dua kasus (Purnamasari \& Raharyani, 2020). Data terbaru dari WHO melaporkan Indonesia berada di posisi ke-23 tertinggi di dunia, sedangkan di Asia Tenggara, Indonesia berada di urutan kedua kasus konfirmasi tertinggi setelah Filipina dengan 125.396 kasus konfirmasi (Kemenkes RI, 2020b). Data ini diperkirakan akan terus bertambah.

Kasus Covid-19 menyebar di 34 provinsi dengan kasus terbanyak di DKI Jakarta. Penambahan kasus positif terus terjadi, dimana pada 24 Juli 2020 masih dengan angka 95.418 pasien yang terkonfirmasi, akan tetapi terjadi peningkatan secara siginifikan pada tanggal 26 Agustus 2020 mencapai 160.165 pasien positif, 115.409 sembuh, dan 6.944 yang meninggal.

Kasus di Aceh pertama kali terjadi pada 23 Maret 2020 yang berasal dari Lhokseumawe. Kasus ini mengalami peningkatan dimana pada 29 Juli Aceh berada diposisi 28 dari 34 provinsi yang terkena Covid- 19 dengan jumlah positif 238 orang dan terjadi peningkatan pada 1 September berada diurutan 21 dengan 1.649 kasus positif. Hingga tanggal 1 September 2020 kasus terus meningkat diberbagai daerah dengan kasus terbanyak di Kota Banda Aceh (positif 531 orang), Lhokseumawe (positif 69 orang), Aceh Timur (39 positif) dan Kota Langsa (positif 28 orang) dengan angka 395 pasien yang sembuh dan diikuti angka kematian sebanyak 66 jiwa (Dinkes Aceh, n.d.).

Desa Paya Bujok Blang Pase merupakan desa yang letaknya di pusat Kota Langsa. Desa ini juga dekat dengan kasus terbanyak di Kecamatan Langsa Kota yaitu di Gampong Jawa dengan jumlah 5 orang kasus positif per tanggal 27 Agustus 2020. Penularan virus corona antar desa sangat mungkin terjadi. Berdasarkan data tanggal 31 Agustus 2020 ternyata satu orang warga Paya Bujok Blang Pase dinyatakan positif Covid-19 (Sistem Informasi Penyebaran Covid-19 Kota Langsa, 2020).

Kondisi pandemi Covid-19 mengharuskan masyarakat melakukan pencegahan dengan mengikuti protokol kesehatan seperti mencuci tangan secara teratur, pakai masker, jaga jarak, tidak melakukan perjalanan jauh, melakukan olahraga, istirahat cukup serta makan makanan yang dimasak hingga matang agar tidak terjadi penambahan kasus dan memperlambat laju dan jumlah kasus Covid-19 (Pratama, 2020).

Oleh sebab itu sangat diperlukan upaya pemutusan rantai penyebaran Covid-19 melalui karakteristik, pengetahuan dan perilaku masyarakat tentang pencegahan Covid-19 sehingga tidak terjadi penambahan kasus yang serius (Morfi, Junaidi, \& dkk, 2020). Hal ini menyebabkan diperlukan penelitian lebih lanjut mengenai karakteristik dan tingkat pengetahuan masyarakat Desa Paya Bujok Blang Pase mengenai perilaku pencegahan Covid-19.

Tujuan

Untuk mengetahui hubungan karakteristik dan tingkat pengetahuan dengan perilaku pencegahan Covid-19 pada masyarakat desa Paya Bujok Blang Pase Kota Langsa.

\section{MATERIAL DAN METODE}

Jenis penelitian ini merupakan studi analitik dengan desain cross sectional. Desain penelitian ini digunakan untuk mengukur variabel independen dan variabel dependen yang dilakukan secara simultan atau dalam satu waktu yang bersamaan. Variabel independen dalam penelitian ini adalah karakteristik dan tingkat pengetahuan masyarakat. Variabel dependen adalah perilaku pencegahan Covid-19. Penelitian ini dilakukan di Desa Paya Bujok Blang Pase Kota Langsa pada bulan Desember 2020 sampai Maret 2021. Berdasarkan penggunaan rumus Lemeshow maka besar sampel pada penelitian ini adalah 
260 KK. Pengambilan sampel dilakukan pada 3 dusun menggunakan metode simple random sampling dan semua populasi yang memenuhi kriteria inklusi. Instrumen penelitian ini menggunakan kuesioner yang terdiri dari kuesioner pengetahuan tentang Covid-19 yaitu 17 pertanyaan dan kuesioner perilaku pencegahan Covid-19 yaitu 14 pertanyaan. Variabel pengetahuan dan perilaku dikategorikan menjadi 3 tingkatan yaitu baik (jika nilai responden 76\%-100\%), cukup (jika nilai responden 56\%-75\%), dan kurang (jika nilai responden $<56 \%$ ). Analisis data dilakukan secara univariat dan bivariat. Analisis univariat dilakukan dengan menggambarkan dan meringkas data dalam bentuk tabel, sedangkan analisis bivariat dianalisis menggunakan metode chi-square.

HASIL

Gambaran karakteristik responden

Tabel 1. Distribusi responden menurut usia

\begin{tabular}{ccc}
\hline Usia & Frekuensi (n) & Persentase (\%) \\
\hline Remaja & 39 & 15,0 \\
Dewasa & 121 & 46,5 \\
Lansia & 100 & 38,5 \\
\hline Total & 260 & 100,0 \\
\hline
\end{tabular}

Sumber: Data primer, 2021

Berdasarkan tabel 1 diatas diperoleh persebaran usia responden paling banyak pada kategori dewasa dan paling sedikit pada kategori remaja.

Tabel 2. Distribusi responden menurut jenis kelamin

\begin{tabular}{ccc}
\hline Jenis Kelamin & Frekuensi (n) & Persentase (\%) \\
\hline Laki-laki & 90 & 34,6 \\
Perempuan & 170 & 65,4 \\
\hline Total & 260 & 100,0 \\
\hline
\end{tabular}

Sumber: Data primer, 2021

Berdasarkan tabel 2 diatas diperoleh persebaran jenis kelamin responden yang paling banyak yaitu perempuan dan yang paling sedikit adalah laki-laki.

Tabel 3. Distribusi responden menurut pendidikan

\begin{tabular}{ccc}
\hline Pendidikan & Frekuensi (n) & Persentase (\%) \\
\hline Pendidikan Dasar & 78 & 30,0 \\
Pendidikan Menengah & 144 & 55,4 \\
Pendidikan Tinggi & 38 & 14,6 \\
\hline Total & 260 & 100,0
\end{tabular}

Sumber: Data primer, 2021

Tabel 3 diatas menunjukkan tingkat pendidikan yang paling banyak ditempuh responden adalah pendidikan menengah dan yang paling sedikit yaitu pendidikan tinggi.

Pekerjaan Tabel 4. Distribusisenesangiden menurut pekerjaan

\begin{tabular}{|c|c|c|}
\hline Tidak & 150 & Persentase $(\%)$ \\
\hline Bekerja & & 57,7 \\
\hline Bekerja & 110 & 42,3 \\
\hline Total & 260 & 100,0 \\
\hline
\end{tabular}

Sumber: Data primer, 2021

Tabel 4 diatas menunjukkan bahwa jumlah responden yang tidak bekerja lebih banyak dibandingkan responden yang bekerja.

Tabel 5. Distribusi responden menurut pengetahuan

\begin{tabular}{ccc}
\hline Pengetahuan & Frekuensi (n) & Persentase (\%) \\
\hline Kurang & 47 & 18,1
\end{tabular}




\begin{tabular}{ccc} 
Cukup & 22 & 8,5 \\
Baik & 191 & 73,5 \\
\hline Total & 260 & 100,0 \\
\hline
\end{tabular}

Sumber: Data primer, 2021

Tabel 5 diatas menunjukkan bahwa sebagian besar responden memiliki pengetahuan yang baik tentang Covid-19.

Perilaku Tabel 5. Distribupiresspemsqen)menurut perilaku

\begin{tabular}{ccc}
\hline Kurang & 39 & Persentase (\%) \\
\hline Cukup & 45 & 15,0 \\
Bai & 176 & 17,3 \\
$\mathrm{k}$ & & 67,7 \\
\hline Total & 260 & 100,0 \\
\hline
\end{tabular}

Sumber: Data primer, 2021

Tabel 6 diatas menunjukkan bahwa responden yang memiliki perilaku baik lebih banyak dibandingkan dengan yang memiliki perilaku cukup dan kurang.

Hubungan karakteristik dengan perilaku pencegahan Covid-19

Tabel 6. Hubungan usia dengan perilaku

\begin{tabular}{|c|c|c|c|c|c|c|c|}
\hline \multirow{3}{*}{ Usia } & \multicolumn{6}{|c|}{ Perilaku } & \multirow{3}{*}{$p$ value } \\
\hline & \multicolumn{2}{|c|}{ Kurang } & \multicolumn{2}{|c|}{$\begin{array}{l}\text { Cuku } \\
\mathrm{p}\end{array}$} & \multicolumn{2}{|c|}{$\begin{array}{l}\text { Bai } \\
k\end{array}$} & \\
\hline & $\mathrm{n}$ & $\%$ & $\mathrm{n}$ & $\%$ & $\mathrm{n}$ & $\%$ & \\
\hline Remaja & 3 & 7,7 & 11 & 28,2 & 25 & 64,1 & \\
\hline Dewasa & 10 & 8,3 & 16 & 13,2 & 95 & 78,5 & 0,000 \\
\hline Lansia & 26 & 26,0 & 18 & 18,0 & 56 & 56,0 & \\
\hline Total & 39 & 15,0 & 45 & 17,3 & 176 & 67,7 & \\
\hline
\end{tabular}

Berdasarkan tabel 7 diatas hasil uji chi square menunjukkan nilai $p$ value sebesar $0,000(\mathrm{p}<0,05)$ yang berarti Ho ditolak atau terdapat hubungan antara usia dengan perilaku pencegahan Covid-19 pada masyarakat Desa Paya Bujok Blang Pase Kota Langsa.

Tabel 7. Hubungan jenis kelamin dengan perilaku

\begin{tabular}{|c|c|c|c|c|c|c|c|}
\hline \multirow{3}{*}{$\begin{array}{c}\text { Jenis } \\
\text { Kelamin }\end{array}$} & \multicolumn{6}{|c|}{ Perilaku } & \multirow{3}{*}{$p$ value } \\
\hline & \multicolumn{2}{|c|}{ Kurang } & \multicolumn{2}{|c|}{ Cukup } & \multicolumn{2}{|c|}{$\begin{array}{l}\text { Bai } \\
\mathrm{k}\end{array}$} & \\
\hline & $\mathrm{n}$ & $\%$ & $\mathrm{n}$ & $\%$ & $\mathrm{n}$ & $\%$ & \\
\hline Laki-laki & 13 & 14,4 & 12 & 13,3 & 65 & 72,2 & 0.427 \\
\hline Perempuan & 26 & 15,3 & 33 & 19,4 & 111 & 65,3 & 0,721 \\
\hline Total & 39 & 15,0 & 45 & 17,3 & 176 & 67,7 & \\
\hline
\end{tabular}

Berdasarkan tabel 8 diatas hasil uji chi square menunjukkan nilai $p$ value sebesar $0,427(\mathrm{p}>0,05)$ yang berarti Ho diterima atau tidak terdapat hubungan antara jenis kelamin dengan perilaku pencegahan Covid-19 pada masyarakat Desa Paya Bujok Blang Pase Kota Langsa.

Tabel 8. Hubungan pendidikan dengan perilaku

\begin{tabular}{|c|c|c|c|c|c|c|c|}
\hline \multirow{3}{*}{$\begin{array}{l}\text { Pendidika } \\
\mathrm{n}\end{array}$} & \multicolumn{6}{|c|}{ Perilaku } & \multirow{3}{*}{$p$ value } \\
\hline & \multicolumn{2}{|c|}{ Kurang } & \multicolumn{2}{|c|}{ Cukup } & \multicolumn{2}{|c|}{ Baik } & \\
\hline & $\mathrm{n}$ & $\%$ & $\mathrm{n}$ & $\%$ & $\mathrm{n}$ & $\%$ & \\
\hline Dasar & 36 & 46,2 & 17 & 21,8 & 25 & 32,1 & \\
\hline Menengah & 2 & 1,4 & 26 & 18,1 & 116 & 80,6 & 0,000 \\
\hline Tinggi & 1 & 2,6 & 2 & 5,3 & 35 & 92,1 & \\
\hline Total & 39 & 15,0 & 45 & 17,3 & 176 & 67,7 & \\
\hline
\end{tabular}


Berdasarkan tabel 9 diatas hasil uji chi square menunjukkan nilai $p$ value sebesar 0,000 $(\mathrm{p}<0,05)$ yang berarti Ho ditolak atau terdapat hubungan antara pendidikan dengan perilaku pencegahan Covid- 19 pada masyarakat Desa Paya Bujok Blang Pase Kota Langsa.

Tabel 9. Hubungan pekerjaan dengan perilaku

\begin{tabular}{|c|c|c|c|c|c|c|c|}
\hline \multirow{3}{*}{ Pekerjaan } & & & \multicolumn{2}{|c|}{ Perilaku } & \multirow{2}{*}{\multicolumn{2}{|c|}{ Baik }} & \multirow{3}{*}{$p$ value } \\
\hline & \multicolumn{2}{|c|}{ Kurang } & \multicolumn{2}{|c|}{ Cukup } & & & \\
\hline & $\mathrm{n}$ & $\%$ & $\mathrm{n}$ & $\%$ & $\mathrm{n}$ & $\%$ & \\
\hline Tidak & 27 & 18,0 & 27 & 18,0 & 96 & 64,0 & 0.230 \\
\hline $\mathrm{a}$ & & & & & & & \\
\hline Bekerja & 12 & 10,9 & 18 & 16,4 & 80 & 72,7 & \\
\hline Total & 39 & 15,0 & 45 & 17,3 & 176 & 67,7 & \\
\hline
\end{tabular}

B erdasarkan tabel 10 diatas hasil uji chi square menunjukkan nilai $p$ value sebesar 0,230 ( $>0,05)$ yang berarti Ho diterima atau tidak terdapat hubungan antara pekerjaan dengan perilaku pencegahan Covid-19 pada masyarakat Desa Paya Bujok Blang Pase Kota Langsa.

Hubungan tingkat pengetahuan dengan perilaku pencegahan Covid-19

Tabel 11. Hubungan pengetahuan dengan perilaku

\begin{tabular}{|c|c|c|c|c|c|c|c|}
\hline \multirow{3}{*}{$\begin{array}{c}\text { Pengetahuan } \\
\text { Kurang }\end{array}$} & & & \multicolumn{2}{|c|}{ Perilaku } & \multirow{2}{*}{\multicolumn{2}{|c|}{$\underline{\text { Baik }}$}} & \multirow{3}{*}{$p$ value } \\
\hline & \multicolumn{2}{|c|}{$\underline{\text { Kurang }}$} & \multicolumn{2}{|c|}{ Cukup } & & & \\
\hline & 38 & $8 \%, 9$ & g) & 19,1 & $\theta$ & 0,8 & \\
\hline $\begin{array}{c}\text { Cukup dan } \\
\text { Baik }\end{array}$ & 1 & 0,5 & 36 & 16,9 & 176 & 82,6 & 0,000 \\
\hline Total & 39 & 15,0 & 45 & 17,3 & 176 & 67,7 & \\
\hline
\end{tabular}

Hasil uji statistik pada tabel 11 diatas menggunakan uji chi square dengan penggabungan sel dan didapatkan nilai $p$ value sebesar $0,000(\mathrm{p}<0,05)$ yang berarti Ho ditolak atau terdapat hubungan antara tingkat pengetahuan dengan perilaku pencegahan Covid-19 pada masyarakat Desa Paya Bujok Blang PaseKota Langsa.

\section{DISKUSI}

Karakteristik responden pada sampel penelitian ini adalah ciri-ciri individu yang mencakup usia, jenis kelamin, pekerjaan, dan pendidikan. Pada penelitian ini karakteristik usia terbanyak adalah dewasa. Pada usia tersebut akan terjadi peningkatan kinerja dan keterampilan fisik seseorang. Menurut Lawrence Green usia adalah faktor yang dapat mendorong terciptanya suatu perilaku (Yaslina, Murni, \& dkk, 2019).

Pada penelitian ini mayoritas jenis kelamin responden adalah perempuan dengan pekerjaan ibu rumah tangga sehingga responden lebih banyak waktu untuk melihat dan membaca informasi. Jenis kelamin termasuk faktor pemungkin atau faktor predisposisi yang memberi pengaruh terhadap perilaku kesehatan seseorang (A. Sari, Rachman, \& Dkk, 2020). Pada penelitian ini tingkat pendidikan sebagian besar responden adalah pendidikan menengah (SMA). Tingkat pendidikan pada dasarnya adalah salah satu faktor yang mempengaruhi pengetahuan dan tindakan seseorang karena pengetahuan akan langsung berpengaruh pada perilaku (Dharmawati \& Wirata, 2016). Pada penelitian ini mayoritas responden tidak memiliki pekerjaan. Lingkungan pekerjaan dapat memberikan pengetahuan atau pengalaman kepada seseorang baik secara langsung maupun tidak langsung yang juga akan mempengaruhi proses seseorang untuk menerima pengetahuan (Mubarak, 2011).

Hasil penelitian didapatkan sebagian besar responden memiliki tingkat pengetahuan dengan kategori baik. Pengetahuan baik responden dalam penelitian ini dibuktikan dari wawasan atau pemahaman responden mengenai pengertian, penularan, gejala, faktor risiko, pencegahan, dan pemeriksaan Covid-19 yang sudah baik. Pengetahuan responden yang umumnya baik dikarenakan banyaknya informasi tentang Covid-19 yang didapatkan dari media massa seperti televisi, koran, baliho, 
poster, dan spanduk. Selain itu, dengan adanya media sosial membuat masyarakat memperoleh beragam informasi dengan cepat dan mudah mengenai Covid-19. Hal ini diakui beberapa responden pada saat diwawancarai peneliti. Faktor lain yang mempengaruhi pengetahuan tentang Covid-19 pada responden yaitu dengan bertambahnya usia maka tingkat pengetahuan akan berkembang sesuai dengan pengetahuan yang pernah didapatkan dan juga pengalaman responden (Monintja, 2015).

Penelitian ini sejalan dengan penelitian Mujiburahman dkk (2020) di Dusun Potorono Banguntapan Bantul D.I.Yogyakarta menunjukkan bahwa 82,7\% responden berada pada kategori baik. Hal tersebut dikarenakan responden yang memiliki pengetahuan yang baik dipengaruhi oleh beberapa faktor seperti usia, pendidikan, media masa, dan faktor eksternal lainnya. Pada penelitian Mujiburahman juga disebutkan responden yang berpengetahuan baik berada direntang usia 36-65 tahun hal ini diakibatkan semakin meningkatnya usia seseorang maka pola pikir dan daya tangkapnya juga akan berkembang (Mujiburrahman, Riyadi, \& dkk, 2020). Penelitian yang dilakukan oleh Sataloff dkk (2021) di Jakarta Selatan mengatakan bahwa responden memiliki pengetahuan baik sebanyak $65 \%$ tentang Covid-19 (Sataloff, Johns, \& dkk, n.d.). Masyarakat dengan pengetahuan baik diharapkan dapat melakukan pencegahan Covid-19 yang tepat. Notoatmodjo menjelaskan bahwa sumber informasi yang diperoleh dari berbagai sumber maka akan membuat seseorang cenderung mempunyai pengetahuan yang luas (Notoatmodjo, 2012c). Penelitian oleh Moudy dkk (2020) yang dilakukan di Indonesia menunjukkan bahwa $76,9 \%$ responden memiliki pengetahuan baik terhadap Covid-19. Hal ini dikarenakan rata-rata responden (82\%) menjawab pertanyaan dengan benar mengenai deskripsi umum virus Covid-19 (Moudy \& Syakurah, 2020). Selain itu, penelitian lain yang sejalan dilakukan oleh Yanti dkk (2020) menunjukkan bahwa masyarakat Desa Sumerta Kelod dikategorikan memiliki pengetahuan yang baik (70\%) terkait pandemi Covid-19 (N. Yanti, Nugraha, \& Dkk, 2020).

Hasil penelitian ini menunjukkan bahwa mayoritas reponden juga memiliki perilaku yang baik terhadap pencegahan Covid-19. Hal ini dikarenakan sebagian besar responden sudah melakukan tindakan pencegahan Covid-19 seperti menggunakan masker saat keluar rumah, jaga jarak, mencuci tangan dengan sabun sebelum dan setelah beraktivitas, etika batuk dan bersin yang baik, menerapkan pola hidup sehat dan menjaga daya tahan tubuh dimasa pandemi.

Perilaku yang baik dipengaruhi oleh tingkat pengetahuan responden yang sudah baik mengenai Covid-19. Faktor lain yang mempengaruhi perilaku baik responden yaitu tersedianya fasilitas dan peralatan yang mendukung responden untuk melakukan pencegahan misalnya adanya sabun dan air yang bersih yang disediakan ditempat umum seperti di cafe, masjid, dan mushola. Lingkungan yang baik seperti masyarakat sekitar, atau tokoh masyarakat yang mematuhi protokol kesehatan juga merupakan salah satu faktor penguat bagi responden untuk melakukan tindakan pencegahan Covid-19. Selain itu, perilaku yang baik juga dipengaruhi oleh tingkat pendidikan responden. Semakin tinggi pendidikan seseorang maka semakin mudah orang tersebut menerima berbagai informasi dan meningkatkan pengetahuan mereka yang akhirnya dapat membentuk perilaku (Budiman \& Riyanto, 2013). Hal tersebut dibuktikan dari hasil penelitian yang menunjukkan responden yang menempuh pendidikan tinggi juga memiliki perilaku yang baik terhadap pencegahan Covid-19.

Hasil penelitian ini sejalan dengan Purnamasari dkk (2020) dengan hasil 95,8\% responden yang memiliki perilaku baik dikarenakan responden dalam penelitian Purnamasari mayoritas sudah menunjukkan perilaku yang baik dalam menjalani protokol kesehatan seperti penggunaan masker saat berada diluar rumah, mencuci tangan dengan sabun atau hand sanitizer sesering mungkin, menghindari kerumunan dan menjaga social ataupun physical distancing (Purnamasari \& Raharyani, 2020). Penelitian yang dilakukan oleh Wonok dkk (2020) menunjukkan bahwa sebagian besar masyarakat Desa Tumani memiliki perilaku yang baik tentang pencegahan Covid-19. Hal tersebut berkaitan dengan tidak adanya kasus Covid-19 sampai akhir bulan Agustus 2020 karena masyarakat desa Tumani memiliki pencegahan Covid-19 yang baik (Wonok, Wowor, \& dkk, 2020). Penelitian yang dilakukan oleh Yanti dkk (2020) pada masyarakat Indonesia dari 1.102 responden di Indonesia, mayoritas responden memiliki perilaku yang baik $(93 \%)$ terkait penerapan social distancing dalam mencegah transmisi Covid-19 di Indonesia (B. Yanti, Wahyudi, \& et al, 2020). Penelitian oleh Sitohang dkk (2021) menyatakan bahwa masyarakat Indonesia bagian Barat melakukan tindakan positif yaitu sejumlah 607 $\begin{array}{lllll}\text { orang } & (74,3 \%) & \text { selama } & \text { pandemi } & \text { Covid-19. }\end{array}$ 
tersebut dibuktikan dengan sebagian besar masyarakat telah melakukan upaya pencegahan penularan Covid-19 seperti tidak pergi ke tempat keramaian, memakai masker saat batuk/pilek dan saat keluar rumah walaupun belum semua bentuk usaha yang dilakukan (Sitohang, Rosyad, \& dkk, 2021).

Selain itu, hasil penelitian menunjukkan bahwa terdapat hubungan antara usia dengan perilaku pencegahan Covid-19 pada masyarakat Desa Paya Bujok Blang Pase Kota Langsa. Hal ini dibuktikan dari jawaban responden kategori dewasa (26-45 tahun) yang memiliki perilaku pencegahan baik. Usia seseorang mempengaruhi pola pokir dan daya tangkap dalam mempelajari suatu objek. Semakin bertambahnya usia maka semakin bertambah pula pola pikir dan daya tangkapnya untuk mempelajari sesuatu sehingga pengetahuan yang didapatpun semakin baik (Budiman \& Riyanto, 2013). Saat seseorang memiliki pengetahuan yang baik tentang Covid-19 maka ia akan mampu untuk menentukan bagaimana dirinya harus berperilaku yang baik terhadap pencegahan Covid-19 (Achmadi, 2013). Hasil penelitian ini sejalan dengan penelitian oleh Afrianti dkk (2021) yang membuktikan bahwa usia memiliki hubungan dengan kepatuhan masyarakat terhadap protokol kesehatan Covid-19. Hal tersebut dikarenakan tingkat kepatuhan terhadap protokol kesehatan lebih banyak dari kategori usia dewasa dibandingkan remaja (Afrianti \& Rahmiati, 2021). Hasil penelitian mendukung teori yang mengatakan bahwa semakin tingginya usia seseorang akan semakin banyak pengalaman hidup yang dimiliki dan semakin mudah untuk menerima perubahan perilaku khususnya dalam kegiatan kesehatan. Seiring bertambahnya usia juga tingkat berpikir lebih matang dalam bertindak (Stuart \& Sundeen, 2007).

Selain itu, hasil penelitian menyatakan bahwa tidak terdapat hubungan antara jenis kelamin dengan perilaku pencegahan Covid-19 pada masyarakat Desa Paya Bujok Blang Pase Kota Langsa. Jenis kelamin memberi pengaruh terhadap perilaku kesehatan seseorang. Jika dibandingkan dengan lakilaki masyarakat dengan jenis kelamin perempuan cenderung memiliki pengetahuan yang lebih baik. Hal ini disebabkan karena masyarakat dengan jenis kelamin perempuan memiliki lebih banyak waktu untuk membaca atau berdiskusi dengan lingkungannya (Wulandari, Rahman, \& Dkk, 2020). Hal ini juga menyebabkan jenis kelamin perempuan mempunyai kecenderungan berperilaku lebih baik dibandingkan dengan laki-laki (A. Sari et al., 2020). Akan tetapi, tidak hanya perempuan saja yang mempunyai perilaku baik dalam kesehatan. Hal ini dibuktikan berdasarkan hasil penelitian yang menunjukkan bahwa baik laki- laki maupun perempuan keduanya sama-sama melakukan perilaku pencegahan yang baik terhadap Covid-19 dengan persentase 72,2\%:65,3\%. Hasil penelitian juga menunjukkan bahwa jumlah responden laki-laki maupun perempuan yang memiliki perilaku kurang jumlahnya juga hampir sama.

Pada penelitian yang dilakukan oleh Prihati dkk (2020) juga mengatakan bahwa jenis kelamin responden tidak memiliki hubungan dengan perilaku dalam pencegahan Covid-19 (Prihati, Wirawati, \& Dkk, 2020). Penelitian yang dilakukan oleh Riani (2021) juga menunjukkan hasil tidak ada hubungan antara karakteristik jenis kelamin dengan praktik pencegahan Covid-19 pada pegawai yang bekerja dari rumah (Riani \& Indraswari, 2021). Jenis kelamin bukan satu-satunya faktor yang mempengaruhi responden untuk melakukan perilaku pencegahan yang baik. Hal ini dikarenakan responden dengan jenis kelamin laki-laki maupun perempuan memungkinkan untuk memiliki keaktifan dan terpapar informasi yang sama mengenai Covid-19.

Hasil penelitian menyatakan bahwa terdapat hubungan antara pendidikan dengan perilaku pencegahan Covid-19 pada masyarakat Desa Paya Bujok Blang Pase Kota Langsa. Hal ini dibuktikan berdasarkan hasil penelitian yang menunjukkan bahwa sebagian besar responden yang menempuh pendidikan tinggi memiliki perilaku pencegahan yang baik sebanyak $92,1 \%$, sedangkan hanya $2,6 \%$ yang perilaku pencegahannya kurang. Hal ini dikarenakan salah satu faktor yang mempengaruhi perilaku responden adalah pengetahuan. Pengetahuan responden sangat erat kaitannya dengan pendidikan. Semakin tinggi pendidikan maka semakin tinggi pula pengetahuannya (Purnamasari \& Raharyani, 2020). Sebaliknya pendidikan yang kurang akan menghambat perkembangan sikap seseorang terhadap nilai-nilai yang baru diperkenalkan. Penelitian ini sejalan dengan yang dilakukan oleh Gannika dkk (2020) yang menunjukkan bahwa ada hubungan antara tingkat pendidikan dengan perilaku pencegahan Covid-19 pada masyarakat Sulawesi Utara. Hal tersebut dikarenakan sebagian besar responden yang berpendidikan menengah dan tinggi selalu/sering melakukan cuci tangan, menggunakan hand sanitizer, menggunakan masker jika keluar rumah, berolahraga, melakukan isolasi mandiri saat sakit atau baru saja melakukan 
perjalanan dari luar daerah, menjaga kebersihan diri serta mengonsumsi makanan yang bergizi (Gannika \& Sembiring, 2020). Penelitian yang dilakukan oleh Afrianti dkk (2021) juga menunjukkan hasil bahwa pendidikan memiliki hubungan dengan kepatuhan masyarakat terhadap protokol kesehatan. Hal tersebut dikarenakan responden dengan pendidikan tinggi lebih patuh terhadap protokol kesehatan Covid-19 dibandingkan dengan responden yang memiliki pendidikan rendah (Afrianti \& Rahmiati, 2021).

Menurut Notoatmodjo, pendidikan seseorang mengenai kesehatan akan berpengaruh terhadap perilaku kesehatan mereka, hal tersebut dikarenakan dengan adanya pendidikan maka akan lebih mudah untuk memperoleh pengetahuan dan terciptanya upaya pencegahan suatu penyakit (Notoatmodjo, 2012b). Jika tingkat pendidikan dan pengetahuan baik, maka perilaku yang terbentuk juga akan baik (Gannika \& Sembiring, 2020). Berdasarkan hal tersebut untuk meningkatkan perilaku sehat pada seseorang, maka perlu juga meningkatkan pengetahuan mengenai kesehatan.

Selain itu, penelitian ini menyatakan bahwa tidak terdapat hubungan antara pekerjaan dengan perilaku pencegahan Covid-19 pada masyarakat Desa Paya Bujok Blang Pase Kota Langsa. Pekerjaan tidak menghambat seseorang melakukan perilaku yang baik terhadap pencegahan Covid-19. Hal ini dikarenakan responden yang bekerja maupun tidak bekerja keduanya tetap melakukan perilaku yang baik terhadap pencegahan Covid-19. Selain itu, jenis pekerjaan yang bukan dalam bidang kesehatan juga menyebabkan responden yang bekerja belum tentu memiliki pengalaman atau pengetahuan kesehatan lebih baik dibandingkan dengan orang yang tidak bekerja. Hasil penelitian ini sejalan dengan Sari dkk (2020) yang menunjukkan hasil bahwa tidak ada hubungan antara status pekerjaan dengan perilaku pencegahan Covid-19. Status pekerjaan tidak berhubungan dengan perilaku pencegahan Covid-19 kemungkinan dikarenakan responden melakukan pencegahan walaupun mereka tidak bekerja (A. Sari et al., 2020). Penelitian yang dilakukan oleh Prihati dkk (2020) menyebutkan bahwa jenis pekerjaan responden tidak memiliki hubungan dengan perilaku dalam pencegahan Covid-19 (Prihati et al., 2020).

Penelitian yang dilakukan oleh Wulandari dkk (2020) menunjukkan bahwa status pekerjaan tidak memiliki hubungan dengan pengetahuan tentang pencegahan Covid-19 (Wulandari et al., 2020). Penelitian yang dilakukan oleh Pratiwi dkk (2020) juga menunjukkan hasil tidak terdapat hubungan antara pekerjaan dengan perilaku ketaatan dalam menjalani protokol kesehatan. Hasil penelitian Pratiwi menunjukkan bahwa responden dengan pekerjaan sebagai pegawai swasta/negeri dan pekerjaan lainnya didominasi dengan perilaku yang baik (Pratiwi, Yani, \& Dkk, 2020). Status pekerjaan tidak menjamin seseorang melakukan perilaku yang baik terhadap pencegahan Covid-19. Hal tersebut dikarenakan perilaku seseorang tidak hanya dipengaruhi oleh pekerjaan saja, akan tetapi banyak faktor lainnya seperti pengetahuan, persepsi, motivasi, dan lain sebagainya (Notoatmodjo, 2010).

Hasil penelitian ini menunjukkan bahwa terdapat hubungan antara tingkat pengetahuan dengan perilaku pencegahan Covid-19 pada masyarakat Desa Paya Bujok Blang Pase Kota Langsa. Berdasarkan hasil penelitian sebagian besar responden yang memiliki pengetahuan cukup dan baik juga melakukan perilaku baik terkait pencegahan Covid-19. Hal tersebut dilihat dari jawaban responden yang memiliki pengetahuan cukup dan baik sudah menerapkan protokol kesehatan dimasa pandemi Covid-19.

Pengetahuan merupakan domain penting dalam terbentuknya perilaku suatu individu. Pengetahuan juga mendasari seseorang dalam mengambil sebuah keputusan dan menentukan tindakan dalam menghadapi suatu masalah (Fuadi, 2016). Menurut Green, pengetahuan merupakan salah satu faktor predisposisi yaitu faktor yang mempermudah terjadinya perilaku seseorang (Notoatmodjo, 2012a). Hasil penelitian ini sejalan dengan penelitian Purnamasari dkk (2020) yang menyatakan bahwa terdapat hubungan antara pengetahuan dengan perilaku tentang Covid-19 pada masyarakat Wonosobo. Hal tersebut dibuktikan dari 144 responden sebanyak 96,9\% (126 orang) dengan tingkat pengetahuan yang baik memiliki perilaku pencegahan yang baik juga (Purnamasari \& Raharyani, 2020). Hal ini mendukung teori adaptasi yang menyebutkan bahwa tingkat pengetahuan yang baik maka akan mendorong individu tersebut untuk melakukan tindakan yang baik juga (Moudy \& Syakurah, 2020). Penelitian yang dilakukan oleh Santoso dkk (2020) di Kota Kediri juga mengatakan bahwa terdapat hubungan antara tingkat pengetahuan dengan tindakan pencegahan Covid-19. Hasil penelitian Santoso didapatkan responden yang memiliki pengetahuan yang baik melakukan tindakan pencegahan yang baik juga (Santoso \&Setyowati, 2020). 
Hasil penelitian yang dilakukan oleh Rachmani dkk (2020) menunjukkan terdapat hubungan antara pengetahuan tentang Covid-19 dengan praktik pencegahan Covid-19 pada masyarakat di Kota Depok, dikarenakan masyarakat dengan pengetahuan tinggi lebih banyak melakukan praktik pencegahan dibandingkan dengan masyarakat yang berpengetahuan rendah (Rachmani, Budiyono, \& dkk, 2020). Penelitian oleh Perdana (2020) juga menunjukkan bahwa terdapat hubungan yang signifikan antara pengetahuan tentang Covid-19 dengan tindakan preventif Covid-19 di masyarakat Kelurahan Kebun Bunga Palembang. Hasil penelitian Perdana didapatkan sebanyak 60,9\% responden yang berpengetahuan baik, memiliki tindakan preventif yang baik (Perdana, 2020).

Menurut Notoatmodjo, pengetahuan merupakan domain kognitif yang sangat berpengaruh dalam tindakan seseorang. Tanpa adanya pengetahuan seseorang tidak mempunyai dasar untuk mengambil keputusan dan menentukan tindakan yang akan dilakukan (Purwoastuti \& Walyani, 2015). Penerimaan terhadap perilaku baru juga akan lebih mudah bila didasarkan oleh pengetahuan (Moudy \& Syakurah, 2020). Semakin tinggi pengetahuan terhadap Covid-19 maka semakin baik pula perilaku pencegahannya (Rachmani et al., 2020).

\section{UCAPAN TERIMA KASIH}

1. Dr. Ir. H. Herman Fithra, ST., MT., IPM., ASEAN. Eng, sebagai rektor Universitas Malikussaleh Lhokseumawe.

2. dr. Muhammad Sayuti, Sp.B (K)., BD, sebagai dekan Fakultas Kedokteran Universitas Malikussaleh Lhokseumawe.

3. dr. Rizka Sofia, M.KT, sebagai ketua Program Studi Fakultas Kedokteran Universitas Malikussaleh Lhokseumawe dan sebagai pembimbing utama yang telah meluangkan waktu, memberikan bimbingan, saran, dan motivasi bagi penulis.

4. dr. Kharunnisa Z, M.Biomed, sebagai pembimbing pendamping yang telah meluangkan waktu, memberikan bimbingan, saran, dan motivasi bagi penulis.

5. dr. Cut Khairunnisa, M.Kes, sebagai penguji utama yang telah memberikan petunjuk, saran dan masukan bagi penulis.

6. dr. Teuku Ilhami Surya Akbar, M.Biomed, sebagai penguji pendamping yang telah memberikan petunjuk, saran dan masukan bagi penulis.

7. dr. Yuziani, M.Si, sebagai dosen pembimbing akademik yang telah memberikan bimbingan bagi penulis.

8. Orang tua penulis ayahanda Drs. Sofiyan dan ibunda Marwati, S.Ag yang telah memberikan doa, dukungan moril dan semangat bagi penulis.

9. Saudara kandung penulis yaitu Muhammad Reza, S.H, Safira Maulia, dan Sadilla Maulida serta keluarga penulis yang telah bersedia membantu, memberikan doa, dukungan moril dan semangat bagi penulis.

10. Teman-teman penulis yang telah membantu dan memberi dukungan.

\section{DAFTAR PUSTAKA}

Achmadi, F. (2013). Kesehatan Masyarakat Teori dan Aplikasi. Raja Grafindo.

Afrianti, N., \& Rahmiati, C. (2021). Faktor-Faktor Yang Mempengaruhi Kepatuhan Masyarakat

Terhadap Protokol Kesehatan Covid-19. Jurnal Ilmiah STIKES Kendal, Vol. 11, hal. 113-124. Budiman, \& Riyanto, A. (2013). Kapita Selekta Kuesioner Pengetahuan dan Sikap dalam Penelitian Kesehatan. Jakarta: Salemba Medika Dahlan.

Dharmawati, I., \& Wirata, I. (2016). Hubungan Tingkat Pendidikan, Umur, Dan Masa Kerja Dengan Tingkat Pengetahuan Kesehatan Gigi Dan Mulut Pada Guru Penjaskes Sd Di Kecamatan Tampak Siring Gianyar. Jurnal Kesehatan Gigi, Vol. 4, hal. 1-5.

Dinkes Aceh. (n.d.). Info Covid-19. Diambil dari https://covid19.acehprov.go.id

Fuadi, F. (2016). Hubungan Antara Pengetahuan dengan Sikap Masyarakat dalam Mencegah Leptospirosis di Desa Pabelan Kecamatan Kartasura Kabupaten Sukoharjo.

Gannika, L., \& Sembiring, E. (2020). Tingkat Pengetahuan dan Perilaku Pencegahan Coronavirus Disease 
2019 (Covid-19) Pada Masyarakat Sulawesi Utara. Jurnal Keperawatan, Vol. 16, hal. 8389. Kemenkes RI. (2020a). Situasi Terkini Perkembangan (Covid-19). 19(September), 17-

19.Kemenkes RI. (2020b). Situasi Terkini Perkembangan (Covid-19). 17-

19.

Monintja, T. (2015). Hubungan Antara Karakteristik Individu, Pengetahuan Dan Sikap Dengan Tindakan PSN DBD Masyarakat Kelurahan Malalayang I Kecamatan Malalayang Kota Manado. Universitas SamRatulangi Manado, Vol. 5, hal. 503-519.

Morfi, C., Junaidi, A., \& dkk. (2020). Kajian terkini CoronaVirus Disease 2019 (Covid-19). In Jurnal

Ilmu Kesehatan Indonesia (Vol. 1, hal. 1-8).

Moudy, J., \& Syakurah, R. (2020). Pengetahuan terkait Usaha Pencegahan Coronavirus Disease

(Covid-19)di Indonesia. 4(3), 333-346.

Mubarak, W. (2011). Promosi Kesehatan untuk Kebidanan. In Jakarta: salemba medika.

Mujiburrahman, Riyadi, M., \& dkk. (2020). Pengetahuan Berhubungan dengan Peningkatan Perilaku

Pencegahan Covid-19 di Masyarakat. Jurnal Keperawatan Terpadu, Vol. 2, hal. 130-

140. Notoatmodjo, S. (2010). Promosi Kesehatan Teori dan Aplikasi. PT Rineka Cipta.

Notoatmodjo, S. (2012a). Kesehatan Masyarakat Ilmu \& Seni. In Rineka Cipta.

Notoatmodjo, S. (2012b). Metodologi Penelitian Kesehatan Cetakan Kedua.

Rineka

Cipta.Notoatmodjo, S. (2012c). Promosi Kesehatan \& Ilmu Perilaku. In Jakarta:

Rineka

Cip

ta.

Perdana, M. (2020). Hubungan antara Tingkat Pengetahuan Covid-19 dan Tindakan Preventif Covid19 diMasyarakat Kelurahan Kebun Bunga Palembang Tahun 2020 (hal. 18). hal. 18.

Pratama, N. (2020). Pengetahuan dan Perilaku Masyarakat Memaknai Social Distancing. 2(1), $1-$ 10.

Pratiwi, M., Yani, M., \& Dkk. (2020). Hubungan Karakteristik Individu Terhadap Perilaku Mengenai

Covi

d-

19 Di Desa Gulingan, Mengwi, Bali. Jurnal Kesehatan, Vol. 13, hal.

112. https://doi.org/10.24252/kesehatan.v1i1.16340

Prihati, D., Wirawati, M., \& Dkk. (2020). Analisis Pengetahuan Dan Perilaku Masyarakat Di Kelurahan

Baru Kotawaringin Barat Tentang Covid-19. Malahayati Nursing Journal, Vol. 2, hal. 780-

790. https://doi.org/10.33024/manuju.v2i4.3073

Purnamasari, I., \& Raharyani, A. (2020). Jurnal Ilmiah Kesehatan 2020. (Mei), 33-

42.

Purwoastuti, E., \& Walyani, E. (2015). Perilaku \& Softskills Kesehatan. Yogyakarta: Pustaka Baru Press. Rachmani, A., Budiyono, \& dkk. (2020). Pengetahuan, Sikap dan Praktik Pencegahan Covid-19 pada

Masyarakat Kota Depok, Jawa Barat. MPPKI (Media Publikasi Promosi Kesehatan

Indonesia): The Indonesian Journal of Health Promotion, Vol. 4, hal. 97.

Riani, E., \& Indraswari, R. (2021). Praktik Pencegahan Covid-19 bagi Pegawai yang Bekerja dari Rumah Covid-19 (Vol. 9, hal. 44-49). Vol. 9, hal. 44-49. https://doi.org/10.20473/jpk.V9.I1.2021.44-49

Santoso, P., \& Setyowati, N. (2020). Hubungan tingkat pengetahuan masyarakat dengan tindakan preventif Covid-19. Jurnal Keperawatan Jiwa, Vol. 8, hal. 565-570.

Sari, A., Rachman, F., \& Dkk. (2020). Perilaku Pencegahan Covid-19 Ditinjau dari Karakteristik

Individu dan Sikap Masyarakat. Journal of Chemical Information and Modeling, Vol. 53, hal. 
$1689-1699$.

Sari, D., \& 'Atiqoh, N. (2020). Hubungan antara pengetahuan masyarakat dengan kepatuhan penggunakan masker sebagai upaya pencegahan penyakit Covid-19 di Ngronggah. Infokes Journal, Vol. 10, hal.

$52-55$.

Sataloff, R., Johns, M., \& dkk. (n.d.). Korelasi Tingkat Pengetahuan dan Sikap Masyarakat terhadap

Perilaku Pencegahan Covid-19 di Jakarta Selatan.

Sistem Informasi Penyebaran Covid-19 Kota Langsa. (2020). Data Covid-19 Kec . Langsa Kota.

20

20 .

Diambil dari https://sipecola.langsakota.go.id/

Sitohang, T., Rosyad, Y., \& dkk. (2021). Perilaku Masyarakat Indonesia Bagian Barat Selama Pandemi

Cov

id

19. Jurnal Kesehatan, Vol. 11, hal. 356. https://doi.org/10.35730/jk.v11i3.775

Stuart, G., \& Sundeen, S. (2007). Buku Saku Keperawatan Jiwa, Edisi 3. In Local Responses to the

English Reformation.

Wonok, M., Wowor, R., \& dkk. (2020). Gambaran Perilaku Masyarakat Tentang Pencegahan Covid19

DiDesa Tumani Kecamatan Maesan Kabupaten Minahasa Selatan. Jurnal KESMAS, Vol. 9, hal. 147156.

World Health Organization. (2020)

WHO Director-General's opening remarks at the mission briefing on

Covid-19. Diambil dari https://www.who.int/director-general/speeches/detail/who-directorgeneral-s-opening-remarks-at-the-mission-briefing-on-covid-19 12-march-2020

Wulandari, A., Rahman, F., \& Dkk. (2020). Hubungan Karakteristik Individu dengan Pengetahuan tentang Pencegahan Coronavirus Disease 2019 pada Masyarakat di Kalimantan Selatan. Jurnal Kesehatan Masyarakat Indonesia, Vol. 15, hal. 42. https://doi.org/10.26714/jkmi.15.1.2020.42-46

Yanti, B., Wahyudi, E., \& et al. (2020). Community Knowledge, Attitudes, and Behavior Towards Social Distancing Policy As Prevention Transmission of Covid-19 in Indonesia. Jurnal Administrasi Kesehatan Indonesia, Vol. 8, hal. 4. https://doi.org/10.20473/jaki.v8i2.2020.4-14

Yanti, N., Nugraha, I., \& Dkk. (2020). Gambaran pengetahuan masyarakat tentang Covid-19 dan perilaku masyarakat di masa pandemi Covid-19 (Vol. 8, hal. 491-504). Vol. 8, hal. 491-504.

Yaslina, Y., Murni, L., \& dkk. (2019). Hubungan Karakteristik Individu dan Dukungan Sosial Dengan Perilaku Pencegahan Stroke Pada Masyarakat Diwilayah Kerja Puskesmas Gulai Bancah. Journal of Chemical Information and Modeling, Vol. 53, hal. 1689-1699. 